\title{
The Erotic Voyeur: Sensorial Spectatorship in Punchdrunk's The Drowned Man
}

Holly Maples

E-mail: holly.maples@gmail.com

Abstract: The cultural industries often privilege the use of sight and sound as our main areas of experience. This is especially the case in theatre criticism; but what of taste, smell and touch? Punchdrunk's manipulation of sensorial experience allows their immersive performance to become both an enticing and destabilizing theatrical arena for the audience. The performance of intimacy constructed through the use of nostalgia-triggering aromas, invitations to explore the set and performers bodies through touch, and the inclusion of oneon-one encounters between performers and audience members, all allow the actor / spectator to be seduced by the 'story-world' of The Drowned Man (2013). With the hyper-reality achieved through the film noir soundscape and the chaotic dance theatre sequences created by the performers, the spectator can delve into a fantasy world of menace and eroticism. This article examines the role of the spectator as erotic voyeur in Punchdrunk's The Drowned Man. Through an examination of the company's use of interactive, sensorial experience where audience members are invited to touch, inhabit and investigate the world around them, Punchdrunk invite the audience to become a part of the world and yet remain separate from it, reinforcing the erotically charged voyeuristic realm of the production.

Keywords: Punchdrunk, immersive theatre, spectatorship, eroticism, the art of seduction, the experience economy

When describing the paradox of diminishing desire in long term relationships, the famous sex therapist Esther Perel identified desire as a phenomenon "fueled" by anxiety and "the 
unknown"(57). The combination of unfamiliarity with intimacy is what produces desire, Perel argues; it is necessary to perceive the object of your affections as both familiar and Other for the erotic imagination to flourish. Perel advises her clients to (re)kindle desire by cultivating this balance of self and Other in relationships; she asserts, "[w]hen we resist the urge to control, when we keep ourselves open we preserve the possibility of discovery. Eroticism resides in the ambiguous space between anxiety and fascination" (57). In many ways, Perel's relationship advice can be used as an instruction guide for attending a performance by the British immersive theatre company Punchdrunk. The experiential nature of their productions, where audiences are invited to explore and interact with the performance, is a space to both surrender control and embrace the unknown.

Punchdrunk exploits Perel's liminal landscape of eroticism by constructing both an intimate and isolative space between performer and spectator. The feeling of intimacy and vulnerability cultivated in their work equally transforms into separation, absence and rejection, while the atmosphere of menace, obsession, and ill-fated attraction creates a highly constructed, and constructable, dark world of sexual fantasy, fetishism and erotic violence. Though encouraged to interact, the spectator is often pushed aside, refused access, or violently removed from the performance space. And rather than the communal, shared experience of the theatre so often trumpeted in immersive performance, the large, interactive installations of Punchdrunk productions create an environment where actors dart quickly across rooms, fostering competition between audience members, who often fight for a view. Moreover, the company's popular one-on-one performances nurture jealousy and feelings of rejection amongst spectators, caused by Punchdrunk's strategic tactic of exclusion where members of the audience are taken alone into a private performance space, leaving the rest outside of the action, with a door slammed in their faces. 
Punchdrunk constructs a landscape of seduction for their audience, a locale where the film noir aesthetic cultivates a perception amongst spectators of being surrounded, encapsulated - indeed, immersed into an erotically charged world. This practice of seduction is used both artistically and as a strategic marketing technique. In The Art of Seduction, by Robert Greene, the seductive tactics of historical lovers like Casanova commingle with modern business practice. Greene instructs his reader to "never be forceful or direct; instead, use pleasure as a bait, play on people's emotions, stirring desire and confusion; inducing psychological surrender" (16). Punchdrunk infuse their performance practice with these methods of seduction, fostering an environment where the seduced theatregoer is left unfulfilled, desiring more from the seducer / performance. The Punchdrunk spectator is left bereft at the end of the night, frustrated by their unfulfilled desires, with their only outlet to eagerly swap stories with other victims of their successes and failures in the bar and long for their chance to return to the world of the production. ${ }^{1}$ Indeed, the large number of props stolen nightly by members of the audience is indicative of the desire amongst fans for mementos kept as love tokens of their all-too-brief seductive encounter. ${ }^{2}$

With the success of Sleep No More in Boston and New York from 2011 to the present, Punchdrunk has been under increasing scrutiny by scholars, bloggers and theatre critics for its immersive techniques and is often used as a poster child to explore the successes and limitations of the genre. Much has been written on the ethical ramifications of their claims of a personal, shared experience between company and spectator (see Machon;

\footnotetext{
${ }^{1}$ Punchdrunk's fans are known to see the performance several times during a run. Some interviewed stated that they have seen The Drowned Man 10 or even 25 times. There is a category of 'superfans' who may have seen Sleep No More in New York City 30-40 times (see Silvestre).

${ }^{2}$ During the run of The Drowned Man, the design team made triplicates of props weekly to replace items stolen on the set. A Sleep No More performer described some of the stolen goods: "love letters in Malcolm's office, Lady Macbeth's letters [...], Lady Macduff's fur coat [...], the nurse's jacket [...], Macbeth's coat that he gets hung in" (see Sparks qtd in Dubner).
} 
Woyzniak). However, the following is neither a sociological study of audience reception to Punchdrunk productions, nor an extensive project on immersive performance. Rather, I am interested in examining the seductive landscape of Punchdrunk's The Drowned Man (2013) and how it fosters tension between participant and witness, between individual and group, and the ways in which audience members negotiate their role in the construction of seduction and intimidation, which are both a device of the company and of the erotic imagination of the viewer. What is the appeal of such a fantasy in contemporary culture, and how do the spatial, bodily and sensorial practices of the company construct an experience of eroticism for audience members? Through an examination of their use of interactive, sensorial experience where audience members are invited to touch, inhabit and investigate the world around them, the following interrogates how The Drowned Man invites the audience to become a part of the performance and yet remain separate from it through seductive, sensorial practice, reinforcing the erotically charged, voyeuristic world for the spectator.

My research is drawn from theoretical, anecdotal and embodied practice. Over the run of The Drowned Man I worked as a volunteer design assistant for the company, participated in a design workshop and in two intensive performance workshops with the choreographer, Maxine Doyle, and other members of the ensemble in August 2013 and July 2014. I have briefly performed on The Drowned Man sets and experienced first-hand the challenge for a performer to draw, guide and keep an audience member's physical and emotional engagement when often being eclipsed by the evocative installations crafted by the design team. I also use backstage gossip, my subjective experience as audience member, as well as personal interviews with performers, other audience members, fan sites, blogs and comments 
from what the company refer to as 'superfans' of both The Drowned Man and Sleep No More. ${ }^{3}$

\section{The Art of Seduction}

Leave your friends behind and explore the building on your own-fortune favours the bold.

If you want action and story find a character and follow them.

If a character looks you in the eye and takes your hand-go with them, you're in for a treat.

If you want secrets and mystery follow your instincts and let the building guide you.

Be brave, the more curious you are, the more you'll discover.

Run, creep and glide through the building and let yourself get lost in a sea of ghosts. Always trust Mr. Stanford. (Barrett qtd. in Loveridge; emphasis original)

Punchdrunk constructs an experience for its audience that negotiates between collective and personal encounters, between voyeurism, traditional site specific audience / performer relationships, role playing and intimate encounters when audience members become a part of the story. It is the very interactive and individualistic nature of the productions that are often trumpeted as unique amongst theatrical performances. As one commentator reflected upon her experience, "[f]ollowing the characters we found into a bedroom, where they began to take off one another's clothes, made me feel voyeuristic and a bit awkward. I suppose this isn't much different to a normal play, however; it's just more up-close and personal. We so often wish to be a fly on the wall in someone else's life, and Punchdrunk create this experience" (Goode). The popularity of immersive theatre in Britain and North America is

\footnotetext{
${ }^{3}$ I saw two performances of Sleep No More in New York City in 2012 and 2013, and attended four performances of The Drowned Man.
} 
perceived by many theatre critics and audience members as indicative of our desire for intimacy in an increasingly mediated culture. Punchdrunk's creation of fantasy worlds in non-traditional performance venues, according to reviewer Sarah Hemming, constructs an "imaginary landscape inside the shell of what was once a working reality" and "offer a visceral alternative to the quick-fix, touch screen interaction of our technology-heavy world". The tactile nature of their productions, where you are invited to "taste, touch and smell" the world, is claimed to be "real" (see Hemming) because of its reliance on sensorial experience by the spectator.

The Drowned Man, which performed over 2013-14 in London, creates a virtual world over four floors of an old postal sorting building in Paddington. Combining story lines from Georg Büchner's Woyzeck (1837) and Nathanael West's The Day of the Locust (1939), the company creates an immersive performance of Hollywood in the 1960s. Like most of their adult productions, The Drowned Man centres on a dark, seductive and violent world evocative of film noir, with an aesthetic and sound design influenced greatly by auteurs such as Alfred Hitchcock and David Lynch. Punchdrunk's manipulation of sensorial experience allows their immersive performance to become both an enticing and a destabilizing theatrical arena for the audience. With the hyper-reality achieved through the atmospheric soundscape, sensorial installations, and chaotic dance theatre sequences, the spectator can delve into a fantasy world of menace and eroticism.

\section{Playing Dirty: Fantasies of Self and the Erotic Imagination}

To compensate for the difficulties in their lives, people spend a lot of their time daydreaming, imagining a future full of adventure, success, and romance. If you can create the illusion that through you they can live out their dreams, you will have them at your mercy. Aim at secret wishes that have been thwarted or repressed, stirring up 
uncontrollable emotions, clouding their powers of reason. Lead the seduced to a point of confusion in which they can no longer tell the difference between illusion and reality. (Greene 15)

When investigating what Antonio Gramsci described as opera's "pestiferous" effect of "something deeply felt and experienced" by its audience, film scholar Teresa de Lauretis argued that this fictional space is necessary to allow the spectator to perform "private fantasies, daydreams and reveries by which individual subjects imagine or give images to their erotic, ambitious or destructive aspirations" in the public sphere (378). The dark and erotic fantasies played out in the opera house, she claims, become a public performative, a safe space for fantasies to be experientially imagined by the audience before they return to their everyday lives. Fantasy, de Lauretis contends, "is a creative activity that animates the imagination and produces [...] scenarios in which the subject [becomes] a protagonist or in some other way present" (303-304). According to Sigmund Freud, human beings "benefit by a certain degree of relaxation of censorship"(146-147) in the imagined space, while the negotiation of moral and immoral behaviour becomes mutable through these fantasies of self (492). This has continued into the 21 st century through film and other popular entertainments, enabling audience members to merge their own self-fantasy with that of the performance's virtual world. "The film moves us (in both senses of the word) along with it, binding fantasy to mirages; placing, shifting, and re-positioning the spectator as a figure in that imaginary, imaged world, as one present or emotionally participating in it" (De Lauretis 303). Felix Barrett, Artistic Director of the company, claims that sensorial experience in Punchdrunk's work allows the spectator to merge with the fantasy world around him or her. Barrett perceives the audience's role as one of selective viewer, who can arrange and 
rearrange the performance according to their whims or chance encounters, becoming "the editor of their own film" (Barrett qtd. in Loveridge).

Punchdrunk seduce audience members through a variety of techniques, creating a world where the fantasy of the production, constructed by the company, and the fantasy of self, created by the spectator, commingle through sensorial, bodily and emotional engagement. It is this merging of self with fantasy enhanced by each individual's choice of route, behaviour and interactivity that appeals to many members of the public. The use of masks heightens the sense of salacious pleasure for some audience members. Their perceived anonymity allows them to engage more fully with the fantasy world, releasing them from behaviour of their everyday reality. As one audience member argued, “[i]t wouldn't have worked if they'd guided me; part of what blew me away was the experience of being an anonymous voyeur, of learning what I'd do if no one knew it was me" (drinkthehalo qtd. in Gianniba). Through manipulative devices in Punchdrunk's scenography, choreography and sound design, spectators are invited to delve into the sexual and voyeuristic fantasies of self and Other highlighted in the production.

Punchdrunk is greatly influenced by film noir, and a filmic relationship between spectator and performance. Barrett desires to create a charged atmosphere where the spectator enters into a film “storyworld”(Doyle, M., interview with author) depicting a heightened reality of jealousy, longing, seduction, and violence. The tension and threat of a dark, sexually charged atmosphere is nurtured through the elaborate design installations. Many spaces are constructed to seem embodied, appearing "haunted"(see Hemming) by the physical presence of their fictional characters. This device heightens the spectator's voyeuristic interaction with the space. For some members of the public, the perceived presence of the absent character enhances their fantasy of becoming the flâneur: "I am a voyeur, staring and staring, trying to take in as much of that closed room as I can. I am the 
camera; tracking slowly down - record, record" (Arfman). The scale of the production often means that one can enter a room alone, with few, if any, other spectators to interact with, giving the audience member the illusion of being an uninvited intruder. The spaces themselves are evocative of a character's personal and private settings - settings being invaded by the sole spectator. As the public inspect the empty room, the objects often give witness to the threat of violence, desperate love or obsession found within an individual character. The spectator is encouraged to pry into the character's possessions, fingering the objects, diaries, letters, and clothing while sitting in their chairs, on their beds, or exploring their wardrobes, drawers, or other intimate pieces of furniture. Their engagement with the space is a violent act of intimacy by the spectator. The invasive discovery of characters' secret thoughts and hidden desires can become an enticement for seductive arousal of curiosity, sensual engagement, and spectatorial obsession with the space itself. The space becomes the seducer.

\section{A Choreography of the Senses: Touch, Taste and Smell in Punchdrunk}

Sensorial experience is integral to all aspects of Punchdrunk's work. The performers train in contact improvisation, where much of the choreography is devised through a nuanced relationship of performers' bodies in contact, and a visceral awareness of skin, muscle and bone leads the performers to become extremely aware of the smallest pressure upon their bodies from an outside source. Their use of Anne Bogart's and Tina Landau's Viewpoints (see Bogart and Landau) also raises their awareness of their physical environment, where all aspects of the space, audience and actors are used as inspiration for physical and emotional response. Ohad Naharin's method of Gaga, which enhances both minute gestures and violent contrasts of rhythm, remains central to their choreography. A movement vocabulary that releases unconscious, often playful, impulses, Gaga shifts the focus between body parts 
through rhythmic transitions and improvised gestures fostering an acute awareness of the body in performance. Through this technique, as a Gaga dancer articulates, "small gestures can be both delicate and explosive" (Holmes). All of these techniques focus on heightening the relationship between performers' bodies, sensorial experience and spatial awareness. Combining this choreographic style with the highly seductive genre of film noir, Punchdrunk construct a world both outside and inside of reality, where time itself, and physical gesture, are extended into a fantasy world of sensorial experience.

The integral use of touch and tactile response in their choreography is itself a demonstration of the erotic landscape. According to the sociologist Steve Connor, touch, in many ways, is intimacy. As he queries, "'tactile, tangible, touched, torn, touching itself, soliciting touch' - why are these words so erotic, what is it about touch that already brings up ideas of intimacy?" (32). Doyle argues that their use of contact improvisation to evoke an atmosphere of intimacy amongst their performers, and the use of touch in their one-on-ones with audience members, was inspired by a study from 1976 on nonverbal communication and customer experience. As sociologist Jacob Hornik summarizes the conclusions of the study:

Fisher, Rytting and Heslin (1976) investigated the effects of a brief 'accidental' touch in a nonintimate context. They had male and female clerks return library cards to some students by placing their hands directly over the students' palms, making physical contact; other students were not touched. Outside the library, students were given an instrument to measure their evaluation of the library. Students who were touched, especially the women, evaluated the library significantly more favorably than those who were not touched. (Hornik 449) 
According to this study, in spite of only $57 \%$ of the customers noticing that they had been touched by the librarian, not only did the researchers find that the library users had a "more favourable" experience from the strategic use of touch, but they were also more likely to return books on time (Dillard and Pfau 450). Sociologist Jacob Hornik, who was examining the use of tactile response and consumer experience, argues that studies such as these prove the persuasive power of touch, which "facilitates positive moods, increase[s] attentional arousal, and enhance[s] the feelings [of] an interpersonal bond" in consumers (457).

Paul Rodaway’s book on physical interaction with sensorial experience, entitled Sensuous Geographies, describes sensorial perception as a social, as well as an individual experience. The senses of touch, smell, sight and hearing are both a medium for individuals to perceive information about their environment and "a kind of message"(37) where understandings of that world are constructed. In this way sensorial experience is lived and imagined, a union of mind and body (37). One audience member reflected on her encounter with the soundscape of Punchdrunk's Sleep No More as a sensorial, tactile experience. The sound of the forest "enveloped" her, offering her a "singular experience" through its immersive quality (Amy). For this commentator, it is not just her encounter with the sound that becomes immersive, but her engagement with the fantasy world by being immersed within it. She does not hear sound, she is enveloped by it. This soundscape, which she associates with the forest she is walking through, allows the audience member to explore fantasies of self, triggered not only by the world of Sleep No More, but by the larger genre of film noir the sound is influenced by. For Rodaway, this union of oneself with sensation is also a space for reciprocity between the sensation and the sensor. As he argues, "[a]t its most attentive, each sense can imply a kind of reciprocity. This is most evident in the case of touch, where to touch something also implies permitting that something to touch you" (37). 
To perceive a sensation is to experience a desired, or unwanted, intimate encounter. There is a tacit consent, or invasive force, experienced in sensing something else.

Punchdrunk utilize this union of spectator and performance through their attempt to foster imagined experience through sensorial practice. They seek out smells that trigger an emotion or a memory, sounds that remind one of certain films, time periods, or other evocations of nostalgia, and light and shadow to manipulate moods. During the rehearsal process, the designers, Beatrice Minns and Livi Vaughan, seek out a variety of scents for each installation; before choosing a particular scent, they ask members of the team to articulate what feelings or memories are evoked by the scent, illustrating their use of smell to manufacture an emotional, as well as physical, relationship to the space. The invasion of the senses found in their productions is in many ways an invading force of seductive or mood enhancing properties.

A chance 'one-on-one' encounter I experienced in The Drowned Man emphasises the attempt to seduce the spectator through an overload of the senses. An emotionally imbalanced cowboy grabbed me and dragged me into his trailer where he proceeded to remove my mask, stare longingly in my eyes, give me a shot of whiskey, take one for himself, and then began to rave with despair about the end of the world, weeping. He proceeded to blindfold me and walk me through the space while citing text from Revelations about the rain of water, sand, wind and fire on the Day of Judgement. The actor poured each element into my hands, and, finally, spoke about the fire of hell while bringing a hot, red light close to my blindfolded face. While this occurred, he held me close in a desperate embrace, whispering the text in my ear. Inevitably, the seducer then rejects the seduced, and he violently tore off my blindfold and cast me out into the open space. Alone and dazed, I wandered into another area, a Western bar, sat stunned, and then was given another shot of whiskey by the barman before being thrown off my chair by yet another cowboy beginning a new violent dance sequence. 
For many spectators, one-on-one performances as the one described above feel like a deeply personal experience; indeed, the sensation of sexualized intimacy through touch, close dancing and hushed communication can feel, to some, like the experience of a short-lived but very 'real' love affair. According to Josephine Machon, one-on-one performances appeal to contemporary audiences because " $[\mathrm{t}]$ he alienation from real intimacy in our workaday lives, via such forums as Facebook, can be addressed by immersive practice, which demands bodily engagement, sensually stimulates the imagination, requires tactility" (26). However, though there is no denying the challenge our increasing use of social media as a society is placing on our communication skills, paradoxically the charged nature of the Punchdrunk encounter may be amplified by the very lack of true intimacy between spectator and performer, awakening the inherent negotiation between desire and fear Lauren Berlant associates with intimate interactions (281-88). In many of Punchdrunk's one-on-one encounters, strategic devices are used to leave many spectators, like myself, feeling dazed and 'stunned' by the encounter, augmenting the erotic fantasy of a submissive / dominant relationship found within the oneon-one.

In my personal experience of one-on-ones, the company use tactics to draw you in, but also remove you from the world of the show, allowing the spectator to remain in a liminal space, unsure of what they should do or how they should behave. ${ }^{4}$ A similar encounter in both productions of Sleep No More and The Drowned Man offered insight into how they use well practiced and scripted techniques to create a sense of performative intimacy. In the doctor's office of The Drowned Man, and a similar chemist's shop in Sleep No More, the performer led me into an isolated room or office, inspected me, took off my mask and then became noticeably unsettled and distressed. As the character became disturbed and kept

\footnotetext{
${ }^{4}$ I experienced eleven one-on-ones during The Drowned Man and three at Sleep No More. Others were described to me by friends and audience members, and by Punchdrunk company members.
} 
intense eye contact, he then either whispered in my ear (extending the intimate tactile encounter) or touched my face as he said, "You look like her", and then, after a moment of distress, put my mask back on and abruptly threw me out of the room. The contrast between an extension of the temporal space and slow and lingering touch, the intensity of the gaze, the emotional display of vulnerability by the character / actor, and the abrupt, almost violent, removal from the intimate performance space are devices the company have used in a number of one-on-one encounters I have had with different members of the company in both productions. It is the combination of physical proximity, affective encounter, and abrupt contrasts of tempo that adds to the charged atmosphere of such encounters. The spectator is exposed by the removal of the mask, which can often feel more like a metaphoric undressing as it breaks the 'rules' of the fantasy world. The emotional, empathic performance creates a fiction that the spectator has brought out a revelation of the character's past experience or secret pain. However, this revelation only goes so far, heightening the feeling of disorientation, suspense and mystery in the eroticized landscape. Through this expression of vulnerability, more questions emerge and very little is truly revealed, allowing the entire experience to create a sense of confusion for the spectator, where secrets, rather than being revealed, are actually deepened.

Punchdrunk choose audience members for one-on-ones selectively. They seek out receptive spectators who give them 'energy' through intense eye contact and physical 'openness', and reward loyal followers who trail actors through the space over the course of the evening; furthermore, they also ignore or 'punish' bad audience members who vie too aggressively for the actors' attention (see C. Doyle). The dependence of willing participants on actors' choices illustrate the negotiation of power between spectator and performer. The company's focus on audience engagement is not only necessary for the spectator's experience with the world of the production, but also for the affect of the world of The Drowned Man on 
other spectators experience. The physical bodies of audience members in masks emphasizes the voyeuristic and dreamlike nature of the production. The company rely on the willingness of spectators to interact with the multiple fictions constructed in the performance of time, space and intimacy in order to co-create an erotically charged world. The spectator, as well as the performer, may become a seducer, or a fickle lover, in the performance. They encounter, engage with - and reject - spaces, performers and objects as they move from one experience to the next. Many actors feel abandoned when an audience member leaves them mid-scene. Performers also compete for the attention of audience members, sometimes stealing away a member of the public from other actors by grabbing their hand and pulling them to other areas of the elaborate set. They also, like the audience, gossip about particularly inviting audience members during and after each show (see C. Doyle). Spectators remain powerful in their role as witness, audience and engaged observer.

In Punchdrunk's work, the spectator crafts the erotic environment as much as the production does. As one commentator illustrates, her persistence in following the character, an aspiring actress on the film set, appears like a love letter between spectator and performer. Though deeply voyeuristic, the perceived, mutual intimacy existing between herself and the character is apparent:

We enter the dressing room where another man sits at the mirror, staring at his hands. 'Mr Stanford,' she whispers. [...] Then, they kiss. He, she and I are alone in a tiny room, as they kiss so passionately it feels like their last moments on Earth. I feel incredibly voyeuristic. Mr Stanford hands her a lipstick and says to go to studio five, so off we trot, myself as the trailing puppy for this starlet. [...] I continue on my course following the young girl - I have met her lover, and now I have seen her film a 
scene, in her dressing room being made up, and then having a medical exam. I feel like we are just getting to know each other. (Malone)

The relationship between this spectator and the performer, where she is the "trailing puppy" following the character across floors and spying on her increasingly intimate interactions with other characters, illustrates the complex role of audience members in the production. She remains a voyeur, but she also enjoys some agency, often providing a solo audience for the performers, and growing increasingly close to the character she loyally follows. In much of Punchdrunk's work, such loyalty is often rewarded with a one-on-one encounter, where the favoured audience member is given a personal 'intimate' experience, out of site from other spectators.

Maxine Doyle directly associates audience engagement with sensual as well as sensorial experience:

I think that sense of spontaneity is really important, also the sense that they are the only person encountering that event at the time, be it opening a drawer or meeting a character. That sense of being alive and being present is something that we really encourage our audience to discover. It is the heartbeat of our work. There is something quite hedonistic about it in that desire to feel alive and touch but there is also the possibility for them to take responsibility for their reactions. (qtd. in Hemming)

Doyle weaves the personal responsibility of the audience with embodied experience. However, a spectator may be "alive and present" as she claims, but he or she also remains a witness, and therefore someone who is a passive as well as an active participant in the work. 
This dual role encouraged in the production helps build a sense of menace for spectators, heightening their disorientation vis-à-vis the world around them. The construction of hedonistic threat creates, according to Machon, a "Dionysian" space, "placing the perceiver of the art within the art", willing the immersive performance's reality "to become wholly affective, possibly overwhelming and / or intoxicating" to audience members (34), as described by this particular spectator:

There are no boundaries between you and the performers and they can come up to you and touch you, hug you, or even kiss you (on your mask). The production is always based on a story but they twist and turn it to have it become a very dark and, at times, very scary environment to be in. [...] Long story short, I was completely immersed deep inside the characters last night and almost felt like I was performing with them. I got separated from my friends and this dark, mysterious world of the drowned man became my friend. (Mearns)

The performance allows the spectator to fulfill a variety of roles in the work, and thus become both apart from, and a part of, the world of the production.

According to members of the company, the invitation for spectators to actively engage with aspects of the performance allows them to manifest their own darker natures in the production. As Greene instructs would-be seducers, "[p]eople yearn to explore their dark side. Once the desire to transgress draws your targets to you, it will be hard for them to stop. Take them farther than they imagined - the shared feeling of guilt and complicity will create a powerful bond" (16). The company's invitation that "fortune favours the bold"(Loveridge) has produced increasingly aggressive audience behaviour as Punchdrunk has grown in notoriety over the years. Throughout the runs of The Drowned Man and Sleep No More, 
people were caught on a weekly basis having sex during the show, sometimes removing their masks to do so, and gathering a crowd of onlookers who think that their subversive acts are a part of the production (Punchdrunk). Others steal props, or company costumes; some go so far as to heckle or even throw items at the actors, and use other increasingly jarring methods to grab attention, attempting to transform their role from witness to performer, or from outside to inside of the virtual seducer's world. During the run of Sleep No More in New York, one audience member tried to get the attention of Lady Macbeth in an increasingly aggressive manner. As the actress, Tori Sparks, described,

I was performing a solo in the [glass] box, and [...] for whatever reason, this woman decided she was going to throw objects at the glass. And she found anything and everything. There is not much in this room that you can pick up and throw [...] but she found it all [...] the lipstick, the fur, anything, the wet t-shirts, and just started chucking it as hard as she could at the glass. (see Sparks)

Behaviour such as this amongst audience members has made the company create more stringent tactics to safeguard the performers and the public from the 'bold' actions ostensibly encouraged by the company, illustrating the limits to its interactive performance style.

The company's tactics of seduction, intimacy, sensation and rejection are all devices used to entice and repel the spectator, creating a fantasy world of destructive love, pain, rejection and violence that mirrors those found in the performance sources, Woyzeck and The Day of the Locust. However, the seductive power of The Drowned Man's fantasy world is that it is indeed a fantasy. As Greene warns, the object of the seducer is not to create "a claustrophobic relationship with no exits", where the seduced feel that the affair is permanent and "real"(367). The excitement is about the ephemerality of the experience and the seductive 
game of intimacy, not the reality of it. To be a successful seducer, it is necessary " $[\mathrm{t}]$ o make them lose themselves in the present moment, experiencing the timeless depth of your feelings in the present tense [...]; ectstasy is about intensity, not temporal extensity" (367). The attraction of Punchdrunk's work is not for the spectator to become a performer, nor for audience members to engage in actual acts of intimacy with members of the Punchdrunk company, but for the spectator to delve into a, highly contructed, seductive fantasy world where the game of The Drowned Man is continually being negotiated, engaged, resisted and imagined by the erotic spectator.

\section{Works Cited}

Amy. "The Sound of Sleep No More: Part One”. Delirium Dogs Barking: Wrestling with Sound from my Brain to your Ears. 11 March 2012. Web: https://deliriumdog.wordpress.com/2012/03/06/tracking-the-scottish-play-the-soundsof-sleep-no-more/. (Date of access: 1 May 2015).

Arfman. "The Following Snapshots of my Time inside McKittrick". Throw the Rose. 6 April 2014. Web: http://throwtherose.tumblr.com/post/115705922561/the-followingsnapshots-of-my-time-inside-the. (Date of access: 4 July 2014).

Berlant, Lauren. “Intimacy: A Special Issue”. Critical Inquiry 24.2 (1998): 281-88. Print. Bogart, Anne, and Tina Landau. The Viewpoints Book: A Practical Guide to Viewpoints and Composition. New York: Theatre Communications Group, 2005. Print.

Connor, Steve. The Book of Skin. London: Reaktion Books, 2004. Print.

De Lauretis, Teresa. "Popular Culture, Public and Private Fantasies: Femininity and Fetishism in David Cronenberg's M. Butterfly". Signs 24.2 (1999): 303-34. Print.

Dillard, James D. Price and Michael Pfau. The Persuasion Handbook: Developing a Theory of Practice. London: Sage, 2003. Print. 
DubnerStephen J. "Fear Thy Nature". Freakonomics RadioPodcast 141 September 2012. Web: http://freakonomics.com/2012/09/14/fear-thy-nature-a-new-freakonomics-radiopodcast/ . (Date of access: 1 May 2015).

Doyle, Conor. Personal interview. London, 6 August 2013.

Doyle, Maxine. Personal interview. London, 5 August 2013.

Freud, Sigmund. The Standard Edition of the Complete Psychological Works of Sigmund Freud. Vol. 1. Trans. and ed. James Strachey. London: Hogarth, 1908/1962. Print. Gianniba, Poly. “Another Look at The Drowned Man: Five Things I Learned about Punchdrunk (and a few Questions)”. The Other Bridge Project. 17 July 2013, 3:25am. Web: https://theotherbridgeproject.wordpress.com/2013/07/14/another-look-at-thedrowned-man-five-things-i-learned-about-punchdrunk-and-a-few-questions/. (Date of access: 4 July 2014).

Goode, Emma. "Punchdrunk The Drowned Man: A Hollywood Fable”. Emma's Blog. 9 July 2013, 9:13pm. Web: https://emmagoode.wordpress.com/2013/07/09/punchdrunksthe-drowned-man-a-hollywood-fable/. (Date of access: 4 July 2014).

Greene, Robert. The Art of Seduction. New York: Penguin, 2001. Print.

Hemming, Sarah. "It's All about Presence". The Financial Times 7 June 2013. Web: http://www.ft.com/cms/s/2/535443ba-cc68-11e2-bb22-00144feab7de.html. (Date of access: 4 July 2014).

Holmes, Kathryn. "Focus: Modern: Going Gaga”. Dance Spirit 11 (Oct 2007): 8. Print.

Hornik, Jacob. "Tactile Stimulation and Human Response”. Journal of Consumer Research 19.3 (1992): 449-58. Print.

Loveridge, Lizzie. “The Drowned Man: A London Review”. Curtain Up 17 July 2013. Web: http://www.curtainup.com/drownedmanlon.html. (Date of access: 4 July 2014). 
Malone, Justine. "Nature, inside out: The Drowned Man at Temple Studios". One Stop Arts 25 July 2013. Web: http://onestoparts.com/review-the-drowned-man-temple-studios. (Date of access: 4 July 2014).

Machon, Josephine. Immersive Theatres: Intimacy and Immediacy in ContemporaryPerformance. Basingstoke and New York: Palgrave Macmillan, 2013. Print.

Mearns, Sara. "London Inspires". Barre None 20 July 2013. Web: http://www.huffingtonpost.com/sara-mearns/barre-none-londoninspires_b_3628591.html. (Date of access: 4 July 2014).

Perel, Esther. Mating in Captivity. London: Hodder and Stoughton, 2007. Print.

Punchdrunk. Personal interview. London, 4 August 2013.

Rodaway, Paul. Sensuous Geographies: Body, Sense and Place. London and New York: Routledge, 1994. Print.

Silvestre, Agnès. "Punchdrunk and the Politics of Spectatorship". Culturebot 12 November 2012. Web: http://www.culturebot.org/2012/11/14997/punchdrunk-and-the-politicsof-spectatorship/. (Date of access: 4 July 2014).

Sparks, Tori. Interview by Stephen J. Dubner in "Fear Thy Nature". Freakonomics RadioPodcast 141 September 2012. Web: http://freakonomics.com/2012/09/14/fearthy-nature-a-new-freakonomics-radio-podcast/. (Date of access: 1 May 2015).

Woyzniak, Jan. "The Value of Being Together: Audiences in The Drowned Man". Participations: Journal of Reception and Audience Studies 12.1 (2015): 318-33. Print. 